\title{
Denial of Violence: Ottoman Past, Turkish Present and Collective Violence against the Armenians, 1789-2009
}

Review Number: 1809

Publish date: Thursday, 6 August, 2015

Author: Fatma Müge Göçek

ISBN: 9780199334209

Date of Publication: 2014

Price: $£ 35.99$

Pages: 680pp.

Publisher: Oxford University Press

Publisher url: http://ukcatalogue.oup.com/product/9780199334209.do

Place of Publication: Oxford

Reviewer: Joanne Laycock

Histories of the fate of the Ottoman Armenians have long, and understandably, been dominated by two themes. Firstly, the quest for 'proof' of the genocidal intent behind the treatment of the Armenians in 1915. Secondly, the attempt to locate and classify the case of the Armenians within comparative histories of genocide, in other words, does the fate of the Armenians constitute the first modern genocide? The lead-up to the centenary of the Armenian Genocide in April 2015 has however prompted a wave of publications addressing this contested history from new perspectives. Some draw on new research or critical perspectives in order to investigate the causes of the massacre and deportation of the Ottoman Armenian population, for example Ronald Grigor Suny's forthcoming, They Can Live in the Desert and Nowhere Else.(1) Others meanwhile focus on the long term aftermaths of these events, notably Thomas de Waal's, Great Catastrophe: Armenians and Turks in the Shadow of Genocide.(2) Müge Göçek's Denial of Violence: Ottoman Past, Turkish Present and Collective Violence against the Armenians 1789-2009 is thus part of a wider shift in this field from unearthing 'evidence' of genocide towards more nuanced and theoretically informed approaches to not only to causes but also to experiences of Genocide, the responses it engendered and its complex aftermaths.

As the introduction makes clear, Denial of Violence is an 'intensely personal' text which addresses Müge Göçek's own encounter with the wider Turkish past. This encounter, she explains, began through her work on the groundbreaking WATS (Workshop on Armenian Turkish Scholarship) project. This project, initiated by scholars at the University of Michigan, over a course of several years, brought together Turkish, Armenian and international scholars, journalists and other parties to engage with shared, if conflicting, pasts. (3) Given the persistence of state-sponsored denial of genocide by Turkey and the ongoing attempts to restrict or silence those who question the official Turkish narrative Göçek's undertaking should also be recognised as intensely brave. Indeed, the final chapter of this book focuses on the still unresolved case of Göçek's friend and colleague, Hrant Dink, editor of the Turkish-Armenian newspaper Agos and advocate of both Turkish-Armenian reconciliation and democratisation in Turkey. Hrant Dink was murdered in Istanbul in January 2007. His tragic death has prompted an ongoing debate within and beyond Turkey on the question of Armenian/Turkish relations and the possibilities of recognition and reconciliation. 
Denial of Violence is very much a product of this context. It is representative of the growing engagement of historians of this region and period with an expanding range of source material and a willingness to look for new ways to address the question of what may be suppressed or absent from the official Turkish archival record. The text does not go over the old ground of gathering 'evidence' to counter denial narratives (an approach which is increasingly redundant given that countering denial is not a simply a matter of finding the 'right evidence' but of deconstructing narratives and understanding both their origins and their ongoing social and political functions). Instead Göçek approaches this subject from the perspective of historical sociology, examining the autobiographical writings of a wide range of Turkish, Armenian, Kurdish and other figures published in Turkish in the period from 1798 (the start of the 'systematic modernization' of the Ottoman Empire) to 2009. These narratives are addressed in a comparative framework in order to analyse the collective memory of violence against the Armenians, moving beyond 'individual recollections and interpretations to capture patterns of meaning which exist within society at large' (p. 54).

The focus of her analysis is locating and interpreting memories (and silences) regarding violence against the Armenians in order to examine the layers and dynamics of denial over time. However Göçek goes beyond addressing the fate of the Armenians and ultimately poses a much broader question, 'why does violence seem endemic to Turkish state and society?' Her answer is that the fate of the Armenians may be regarded as an act of 'foundational violence' which, unresolved and unacknowledged, has allowed for continued patterns of violence and lack of democratisation: 'As the Turkish state fails to confront the past and the violence contained therein, denial remains normalised, reproducing itself throughout Turkish state and society. True democracy therefore remains a constant challenge for Turkey as its failure to acknowledge the collective violence embedded in its past keeps reproducing such violence in the present' (p. 2). Such acknowledgement of the long term consequences of violence for perpetrators as well as victims as well as an integration of the aftermaths of the Genocide into wider histories of modern Turkish politics and society is an important departure from the existing literature. Nonetheless, given the growing literature on collective memory after violence and conflict in the modern world (especially in the case of the Great War) I wonder if contextualisation of the Turkish case within this literature would have helped to bring this case into dialogue with broader histories of memory and the construction of national identities in inter-war Europe.

Because of the emphasis on memoir Göçek's interpretation differs from previous analyses of denial in that her focus is not solely upon 'the state as the primary actor' (p. 3). Whilst some scholarship on this subject has examined the mechanisms of genocide denial at the level of the state or of academic research in Turkey, the fact of denial is nonetheless often 'taken for granted' in the existing literature, and the social and cultural forces and even individual actors which lie behind it had not yet been adequately investigated. In this respect too, Göçek's work is a very welcome addition to the scholarship. The focus on memoir allows Göçek to effectively address what she terms the 'affective' as well as the 'structural' elements which have shaped denial over the course of the century. Göçek argues that 'affective elements are significant in that they capture the meaning-making processes that inform not only the norms and values of social groups but also their social actions'. Her emphasis on 'affect' is important because it provides insight not only into the motivations behind denial but also into how denial narratives have functioned and what has enabled them to be reproduced so effectively over time (p. 31). However, whilst the authors of the memoirs analysed here are listed in an appendix some feel quite 'anonymous' in the body of text. Although the emphasis here is on the shape (and the silences) of collective memory, in some cases I was left wanting to know more about the identities and experiences of the authors of the texts.

Although the aftermaths and memories of genocide for Armenian communities are not of course the focus of this book, given the subject matter the complexities of Armenian relationships with the past could perhaps have been highlighted a little more in the introductory sections. Statements such as 'Meanwhile, the Turkish denial prevents all Armenians scattered throughout the world from adequately mourning, grieving and thereby eventually coming to terms with their own tragic past' effectively capture the enduring legacies of genocide and denial for many Armenians (p. 31). However they also perhaps gloss over the complexities of Armenian collective memories and social identities and the divisions and tensions which exist within and 
between different communities and generations. Such issues are perhaps beyond the scope of this already wide-ranging work but given the growing theoretical literatures on both collective memory of conflict and 'trauma', they are perhaps a subject ripe for further analysis elsewhere.

The focus of Denial of Violence is not the causes of violence against the Armenians per se, but chapter one helpfully contextualises violence against the Armenians in the advent of modernity, changing economic structures, social relations and visions of the political order in the Ottoman Empire. Göçek explains clearly how 'escalating polarisation in the Ottoman social structure with the advent of western European modernity gradually transformed the preexisting prejudice and discrimination of Muslims against non-Muslims subjects into acts of episodic violence' (p. 124). Over the course of the text she also draws out the continuities and changes in patterns of violence against the Armenians (and other groups) from the late Ottoman period through to the contemporary Turkish Republic. The attention to identifying continuities of ideas, practices and the leadership and elites across the divide of the First World War and founding of the new Republic is a real strength of this work. Göçek identifies four distinct phases of violence and denial: Imperial denial of the origins of violence 1789-1907, Young Turk denial of the act of violence 1908-18, early Republican denial of the actors of violence 1919-73 and late Republican denial of the responsibility for violence 1974-2009. Each of these phases are discussed in separate chapters, all of which have rather different tones and emphases.

In each chapter Göçek addresses a particular narrative and identifies an event central to legitimating it. Chapter one examines the way in which a denial narrative emerged in the aftermath of violence against the Armenians in the 1890s (the 'Hamidian massacres'). In this narrative, the 1896 Armenian attack on the Ottoman bank and sympathetic Armenian relations with the European powers were used by the Ottoman authorities in order to construct an image of the Armenians as a threat to the Empire and thus legitimise violence against them. Chapter two meanwhile focuses on violence committed against the Armenians during the First World War - the Armenian Genocide. Göçek demonstrates that violence against the Armenians is very much present in the accounts and recollections of this period of members of the CUP and local Ottoman authorities. Through her analysis of their memoirs she is able to demonstrate in a concrete manner the ways in which such acts of violence were justified, rationalised and ultimately denied. Göçek is therefore able to shift the focus from the eyewitness accounts of the Armenian genocide by 'westerners' (missionaries \& diplomats) on which many current analyses are based, to accounts from within the Ottoman Empire in the hope that 'the careful documentation of such violence will hopefully enable the contemporary Turks to recognise what happened in their past as narrated by their own ancestors' (p. 227). This chapter echoes other recent interpretations of the causes of the Armenian genocide in emphasising the importance of Ottoman defeat in the Balkan wars and refugee crises which followed in their wake. The contents of the memoirs demonstrate in precise and powerful ways how these events not only created a sense of collective vulnerability or trauma but also re-shaped personal and familial attitudes, mentalities and world views in the lead-up to the genocide.

The following two chapters address the periods currently more readily associated with denial of the Armenian Genocide. Chapter three draws out the continuities between the late Ottoman and the early Republican periods, deconstructing the notion of a clean break between Ottoman past and a new 'modern' Turkey. The central theme of this chapter is that because violence against the Armenians was not acknowledged or reflected upon in the early Turkish Republic it became normalised and would later be deployed against other minorities and opposition groups. Göçek demonstrates how many former Committee of Union and Progress (CUP) members and individuals implicated in violence against the Armenians were gradually integrated into the elites of the new Republic and suggests that these groups joined the new nationalists in 'sustaining and normalising collective violence within state and government they practiced exclusionary nationalism, systematically excluding from the body politic of the nation first the non-muslims and then the Kurds, communists and Islamists' (p. 332). Whilst the inadequacies of the post-war military tribunals of the perpetrators of the genocide are identified as the 'legitimating event' for the denial narratives which emerged during this period, Göçek also addresses the wide ranging mechanisms of the state for controlling narratives of the past through education and the media and traces the evolution of 'exclusionary 
practices' for defining both the nation and its enemies.

The final chapter deviates from the format of those preceding in that it is more personal and feels more highly emotionally charged, tracing not only continued violence but also the emergence of a public 'counter narrative' since 2000. Göçek identifies the ways in which the 'official' narrative has been challenged by memoirs which expose shared Turkish and Armenian pasts, the work of organisations such as the Hrant Dink foundation, journalism and the research of academics at private universities. This chapter in particular draws parallels between earlier violence against the Armenians and the treatment of other ethnic, religious and social groups in modern Turkey, in particular Kurds, Alewites and non-Muslims. In focusing on the work of Hrant Dink and others to challenge the 'exclusionary nature of Turkish nationalism, the official discriminatory Turkish state policy against non-Muslim minorities, and the continued lack of accountability for past collective violence committed against the Armenians' (p. 418) the methodology of this chapter departs a little from the close focus on the analysis of memoir which provides the foundation for earlier chapters.

Göçek also pays attention to the consequences of the attacks and assassinations by the Armenian terrorist groups the Armenian Secret Army for the Liberation of Armenia (ASALA) and the Justice Commandos of the Armenian Genocide (JCOAG). These acts, she argues in reality fostered the development of the modern Turkish denial narrative and allowed the Turkish state to portray Armenians as 'violent perpetrators'. Commenting on a 1983 JCOAG statement Göçek observes that 'it is fascinating that the JCOAG could not comprehend that its own violence not only failed to generate any dialogue: for at least the following two decades it instead bolstered and legitimated the Turkish refusal and resistance to engage in such dialogue' ( $p$. 452). Göçek does not shy away from acknowledging that the 'official' Armenian narrative of modern history is also selective and 'especially overlooks the Armenian massacres of the Turks and Kurds that occurred in the eastern and southern provides at the end of the war and during the Allied occupation' (p. 452). Such willingness to engage with complex and prolonged patterns of violence rather than simply reproduce national narratives in painting all Turks as perpetrators and all Armenians as eternal victims is another strength of this work.

At 656 pages of dense prose, this highly detailed account is by no means an easy introduction to the history or the aftermaths of the Armenian genocide or to Armenian-Turkish relations more broadly. Nor does Göçek's text offer any easy answers or definitive conclusions, in Göçek's own words her frustratingly short conclusion reflects her desire to "capture that awkward, unsatisfactory state of incompletion that the lack of closure produces and has produced for almost a century for the Armenian victims and their descendants' ( $\mathrm{p}$. 447). Rather this text presumes of its readers an understanding of both the history of the fate of the Ottoman Armenians and a willingness to engage with a range of critical theoretical approaches to its aftermaths. Thus for those already engaged in the complex histories of the aftermath of the Armenian genocide or on questions of memory, forgetting and denial of violence in the modern world more broadly, Göçek's work is a welcome addition to the scholarship. However, it seems important to note that although the publication of texts like Göçek's which engage with this contested history from a conceptually and methodologically sophisticated perspective represent crucial developments in the field, they also highlight that introductory texts which would render this subject accessible to undergraduate audiences and take these critical debates beyond specialists are still very much lacking.

\section{Notes}


1. R. G. Suny, They Can Live in the desert but Nowhere Else: A History of the Armenian Genocide (Princeton, 2015), forthcoming. Back to (1)

2. T. De Waal, Great Catastrophe: Armenians and Turks in the Shadow of Genocide (Oxford, 2015). Back to (2)

3. One of the outcomes of the WATS project was the edited volume, A Question of Genocide: Armenians and Turks at the end of the Ottoman Empire, ed. R. G. Suny, F. M. Gocek, and N. Naimark (Oxford, 2011).Back to (3)

Source URL:https://reviews.history.ac.uk/review/1809

\section{Links}

[1] https://reviews.history.ac.uk/item/129414 